\title{
気液相変化により駆動されるゴム人工筋アクチュエータの製作*
}

\author{
加藤 友 規**, 本 多駿 太吕, 程 明 昭** \\ 櫻 木一 樹**, 大 野学***
}

\section{Fabrication of a Miniature Rubber Muscle Actuator Driven by Gas-Liquid Phase Change}

\author{
Tomonori KATO, Shunta HONDA, Mingzhao CHENG, \\ Kazuki SAKURAGI, Manabu ONO
}

\begin{abstract}
The ultimate goal of this research is to develop an artificial micro muscle in which a tiny compressor is installed. Pneumatic actuators, such as pneumatic artificial rubber muscle (PARM) or rubber bellows, have been widely used in many industrial and research fields, since they have merits such as being compact and lightweight. However, the size of the compressor driving the actuator is relatively large. In order to solve this problem, the authors have been researching soft actuators driven by the gas-liquid phase change (GLPC) of fluorocarbon. Fluorocarbon $\left(\mathrm{C}_{5} \mathrm{~F}_{11} \mathrm{NO}\right)$ is a substance that has a relatively low boiling point $\left(50\left[{ }^{\circ} \mathrm{C}\right]\right)$ and a low heat of evaporation $(104.65[\mathrm{~kJ} / \mathrm{kg}]$, whereas that of water is 2,260 $[\mathrm{kJ} / \mathrm{kg}]$ ). In this research, PARM driving experiments utilizing the GLPC were conducted, and a PI control system was built to test step response and frequency response of actuator. The frequency response up to $4.0[\mathrm{~Hz}]$ was clarified and the corner frequency of approximately $1.5[\mathrm{~Hz}]$ was confirmed.
\end{abstract}

Key words : Pneumatics, Pneumatic artificial rubber muscle, Gas-liquid phase change, Pressure control

\section{1. 緒言}

空気圧駆動のロボットに使用される空気圧アクチュエータ の一種である空気圧ゴム人工筋 (Pneumatic artificial rubber muscle, 以下PARM）は, 筋肉の収縮原理を模したもので あり, Fig. 1に示すように空気圧をPARM内部に供給し, 圧 力を上昇させることで径方向に膨張し, 軸方向に収縮して 変位を生じる. PARMは軽量でやわらかく, 同径のエアシリ ンダと比較して数倍の引つ張り力を発揮できる（軽量高出 力）という特徵や防爆性や姿勢保持の点で優れており, 柔 軟な接触動作が要求される対人間用ロボットなど, パワーア シスト機器やマニピュレータへの適用の研究が進められてい る ${ }^{12)}$. しかし問題点として, PARMの駆動源として使用さ れるコンプレッサは大型で, Fig. 2に示すように周辺装置等 を組み合わせると装置全体の小型化が困難になることが挙 げられる. 空気圧アクチュエータが直面するこの問題の解決 策として，コンプレッサを使用しない気液相変化により駆動

\footnotetext{
*平成27年 6 月 3 日原稿受付

**福岡工業大学大学院工学研究科

(所在地 : 福岡県福岡市東区和白東 $3-30-1$ )

(E-mail : t-kato@fit.ac.jp)

***東京都立産業技術高等専門学校ものづくり工学科

(所在地：東京都品川区東大井 $1-10-40$ )

されるアクチュエータに関する研究が進められているが3), 気液相変化を用いてPARMを駆動する際は, $0.3[\mathrm{MPa}$ gauge］以上の圧力発生に約200秒の時間を必要としており, 圧力応答性の改善が課題となっていた ${ }^{4)}$.

そこで, 著者らは応答性の改善 ${ }^{5}$ を目的とし, 本論文で は気液相変化により駆動されるアクチュエータについて, 特に力制御に注目した。 まず，PARMの一般的な特性を測 定し, 次に気液相変化による圧力発生を確認して, PARM の駆動実験を行った。さらにPI制御系を適用し内圧制御を

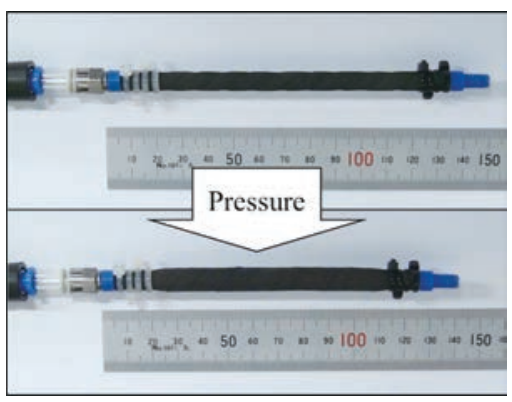

Fig. 1 Pneumatic artificial rubber muscle

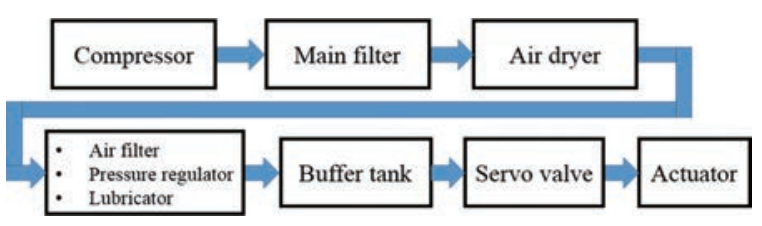

Fig. 2 Pneumatic system 
行った．最後に気液相変化により駆動されるPARMの動特 性を把握するため周波数応答実験を行い, 性能を検証した.

\section{2. 主な記 号}

$$
\begin{aligned}
& A_{F} \text { : 力の振幅 } \\
& A_{P} \text { : 圧力の振幅 } \\
& E \text { : 電圧 } \\
& f \text { : 周波数 } \\
& F \text { : 力 } \\
& G \text { : ゲイン } \\
& P \text { : 圧力 } \\
& P_{r e f} \text { : 目標圧力 } \\
& \dot{P} \text { : 圧力微分值 } \\
& R \text { : 抵抗 } \\
& t \text { : 時間 } \\
& V \text { : 体積 } \\
& W \text { : 消費電力量 } \\
& \dot{W} \text { : 消費電力 } \\
& \varepsilon \quad: \text { 収縮率 } \\
& \theta \quad \text { : 液温 } \\
& \angle \phi_{F} \text { : 力の位相 } \\
& \angle \phi_{P} \text { : 圧力の位相 }
\end{aligned}
$$

\section{3. 気液相変化アクチュエータ}

\section{1 気液相変化の概要}

気液相変化の概要をFig. 3に示す，気液相変化とは，気 体から液体, 液体から気体へと物質を相変化させる現象で ある，液体は，熱を与えられると沸騰が始まり，気体に変 化する，その際に，体積が澎張し，容器内に圧力を発生さ せる．加熱を停止すると熱が奪われ凝縮し液体に戻る。 そ の際に体積が収縮し, 圧力が下降する.

\section{2 気液相変化アクチュエータの概要}

気液相変化アクチュエー夕の概要図をFig. 4に示す。気 液相変化アクチュエータとは液相が気相へ変化する際, 体 積が膨張する現象を利用したアクチュエータである．装置 に取り付けた自作のコンスタンタン製のヒータ（材料： TOKYO WIRE WORKS LTD, $\phi 0.231[\mathrm{~mm}]$, 単位長さあ たりの抵抗值16.02 $[\Omega / \mathrm{m}])$ に電力を与えることで, 加熱 された液体が膨張した後，沸騰し気体へ变化する．その際 に体積が澎張し発生する圧力によってアクチュエータが駆 動する，また，装置から熱を取り除くと，変化していた気 体は液体に戻り体積は収縮する，気液相変化を用いたアク チュエータは，コンプレッサレスのためPARMの長所を生 かしたまま, 装置全体の小型化が可能となる.

\section{3 作動流体}

本研究では作動流体にフッ化炭素 $\left(\mathrm{C}_{5} \mathrm{~F}_{11} \mathrm{NO}\right)$ を用いた。 水とフッ化炭素の比較をTable 1に示す．フッ化炭素は沸点 が大気圧下に拈いて50 $\left[{ }^{\circ} \mathrm{C}\right]$ と低く, 蒸発熱が104.65 [kJ/ $\mathrm{kg}$ ）と水の 22 分の 1 程度しかないため, 僅かな熱エネル ギーの供給・放出で相変化する。熱澎張率は, $20\left[{ }^{\circ} \mathrm{C}\right]$ に おいて $0.00154\left[{ }^{\circ} \mathrm{C}^{-1}\right]$ であり，水の約 7 倍である。 また， 毒性がなく不燃性で安全である。

\section{PARMの静特性実験}

本章では，PARMのモデル化を行うＰARMを錘を取り 付けた状態で駆動させ，その時のPARMの静特性を測定す る実験を行った。本研究で使用したPARM（FESTO MXAM-5-AA）はFig. 1に示したものである.このPARM の各寸法は自然長 $100[\mathrm{~mm}]$, 外径 $6.76[\mathrm{~mm}]$, 内径4.76 [mm] である. 実験装置を Fig. 5に示す. PARMはポテンショメー 夕付きの低摩擦レールに取り付けられ，先端にプーリを介 して錘を取り付けた。

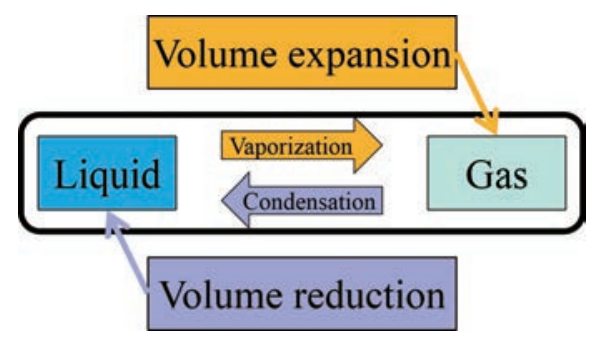

Fig. 3 Gas-liquid phase change

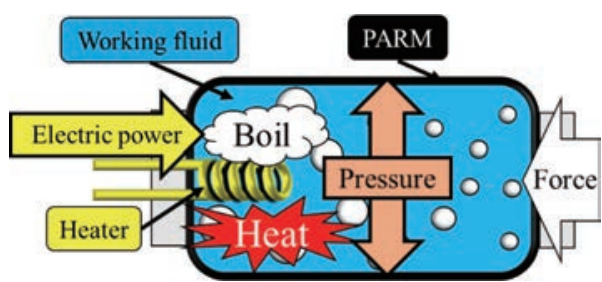

Fig. 4 Gas-liquid phase change system

Table 1 Characteristics of working fluid

\begin{tabular}{|c|c|c|c|}
\hline $\begin{array}{c}\text { Working fluid } \\
\text { (Chemical formula) }\end{array}$ & $\begin{array}{c}\text { Boiling point } \\
(1 \mathrm{~atm})\left[{ }^{\circ} \mathrm{C}\right]\end{array}$ & $\begin{array}{c}\text { Heat of } \\
\text { vaporization } \\
{[\mathrm{kJ} / \mathrm{kg}]}\end{array}$ & $\begin{array}{c}\text { Coefficient of } \\
\text { thermal expansion } \\
{\left[{ }^{\circ} \mathrm{C}^{-1}\right]}\end{array}$ \\
\hline $\begin{array}{c}\text { Fluorocarbon } \\
\left(\mathrm{C}_{5} \mathrm{~F}_{11} \mathrm{NO}\right)\end{array}$ & 50 & 104.65 & 0.00154 \\
\hline $\begin{array}{c}\text { Water } \\
\left(\mathrm{H}_{2} \mathrm{O}\right)\end{array}$ & 100 & 2,257 & 0.00021 \\
\hline
\end{tabular}

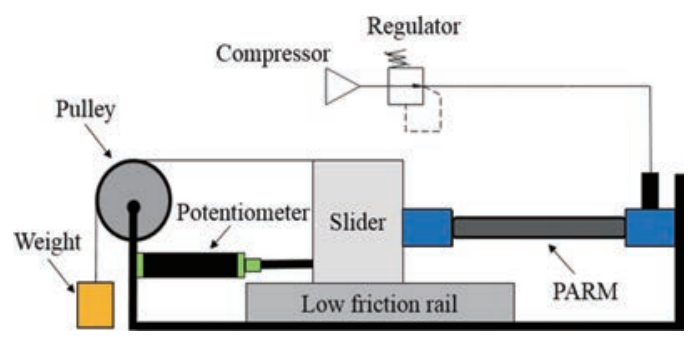

Fig. 5 Experimental apparatus 
錘の質量を0.5 [kg] $(F=4.9[\mathrm{~N}]), 2[\mathrm{~kg}](F=19.6[\mathrm{~N}]), 3$ [kg] $(F=29.4[\mathrm{~N}])$ とし, PARMの内圧 $P$ を $0 \rightarrow 0.4 \rightarrow 0$ [MPa gauge $]$ と変化させ, その際PARMの変位をポテン ショメータで測定し, PARMの内圧と収縮率の関係を求めた. 実験結果をFig. 6に示す. 外力 FとPARMの収縮率 $\varepsilon$ と内 圧 $P$ の関係は補正係数を用いた(1)式で表すことができる ${ }^{6)}$.

$$
F=P\left(a_{1} \varepsilon+a_{0}\right)-\left(b_{1} \varepsilon+b_{0}\right)
$$

実験結果より上式の各係数を最小二乗近似を用いて， $a_{1}$ $=2304.2 ， a_{0}=103, b_{1}=1526.9, b_{0}=-10.1$ と求めた.

同様にFig. 5の実験装置を使用し，錘の質量を0.5 [kg] $(F=4.9[\mathrm{~N}]), 2[\mathrm{~kg}](F=19.6[\mathrm{~N}])$ とした場合のPARM の収縮率 $\varepsilon$ と体積 $V$ の関係を測定した．測定結果をFig. 7 に 示す. PARMの収縮率と体積の関係は, PARMに加えられ る荷重によらないことが過去の研究で報告されており ${ }^{7)}$, 最小二乗近似により $(2)$ 式で近似することとした.

$$
V=-69.08 \varepsilon^{2}+24.08 \varepsilon+1.75
$$

以上は一般的なPARMの静特性のモデル化であり, 本論 文の次章以降で本章の全ての結果を利用するわけではない が，本論文で使用するPARMを駆動するには， $0.2[\mathrm{MPa}$ gauge ］から 0.4 [MPa gauge $]$ 程度の内圧力を発生すれば よいことがわかる.

\section{5. 気液相変化によるPARM駆動実験}

\section{1 圧力発生実験（オープンループ）}

気液相変化による圧力の発生の様子を観察するため, 固 定容器を用いて圧力発生実験を行った。 今回の目標圧力は

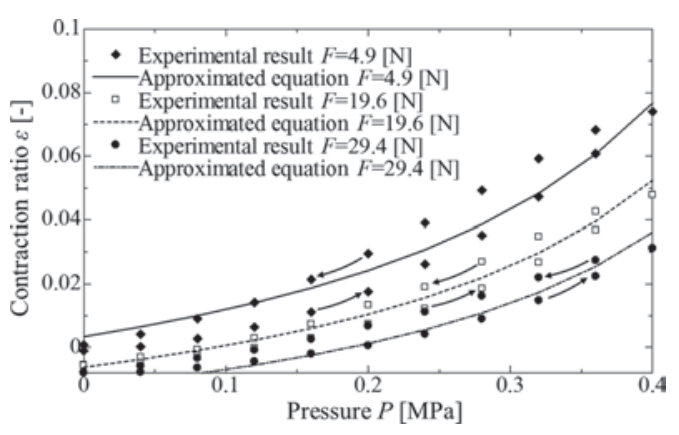

Fig. 6 Static characteristics of PARM

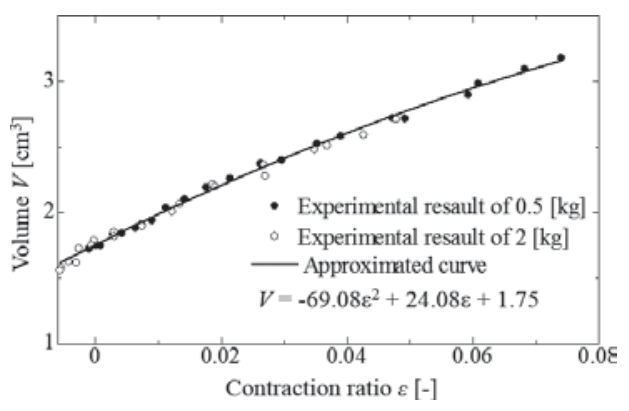

Fig. 7 Volume change of PARM
PARMの駆動に使用する0.35［MPa gauge］である. 実験装 置をFig. 8に示す. 本章における実験では, $30\left[\mathrm{~cm}^{3}\right]$ の固定 容器 (円筒部材質 : アクリル, 高さ : $42.4[\mathrm{~mm}]$, 内径 : 30 $[\mathrm{mm}]$, 側面積 : 3,996.1 [mm²] ; 上下面 材質 : アルミ, 上下 総面積 : 1,413.7 [m²]）に, 前述のフッ化炭素を満タンに充 填した. 作動流体は装置下部のコンスタンタン製のヒータ （抵抗值3.7 $[\Omega] ）$ に電力を与えることにより加熱され沸騰 する．また，装置上部には圧力センサ（SMC PSE510-R06） を取り付けた。

実験においてはオープンループにて, ヒータに電力を $331[\mathrm{~W}]$ (電圧35 $[\mathrm{V}]$, 電流9.46 [A]) 与えることで, 固 定容器内の圧力を大気圧力状態から上昇させる実験を行っ た. 圧力の上昇過程をFig. 9に示す.この実験結果より, 気液相変化による圧力の発生を確認した.

\subsection{PARM駆動実験（オープンループ）}

気液相変化を用いてPARMの内圧を 0.3 [MPa gauge $]$ か ら0.35［MPa gauge］まで変動させる実験を行った，実験 装置をFig. 10に示す. PARMは固定容器の上部に取り付け, さらにPARMの上部には力を測定するロードセル（TCLZ50NA）を取り付けた. また, 作動流体は固定容器と PARM内部を満たすように充填した，前節と同様に，実験 は電力を331 $[\mathrm{W}]$ （抵抗3.7 $[\Omega]$, 電圧35 $[\mathrm{V}]$, 電流9.46 [A]）とした. この実験では，一度固定容器内圧力が 0.35 [MPa gauge $]$ に達した後にヒータへの電力供給を遮断し, 0.3 [MPa gauge] まで降下させた. その後, ふたたび 0.3 [MPa gauge $]$ から電力を供給し, 0.35 [MPa gauge $]$ まで 容器内圧力を上昇させ, 0.35 [MPa gauge $]$ に達した際に 電力を遮断し圧力を降下させ, この時の固定容器内の圧力 を測定した。

測定された固定容器内の圧力值と算出した圧力微分值を 示した実験結果をFig. 11に示す. 固定容器内圧力が 0.3 [MPa gauge $]$ から0.35 [MPa gauge $]$ まで上昇するのに要 した時間は0.21 [s]，下降に要した時間は2.3［s］であった. また, 電力供給を開始した直後の容器内圧力の圧力微分值 は0.54 [MPa/s], 電力遮断後は $-0.11[\mathrm{MPa} / \mathrm{s}]$ であるこ とを確認した。この圧力微分值より, PARM駆動のロボッ トシステムを 1 ～ $2[\mathrm{~Hz}]$ 程度の動特性で動かせる可能性 を示した。

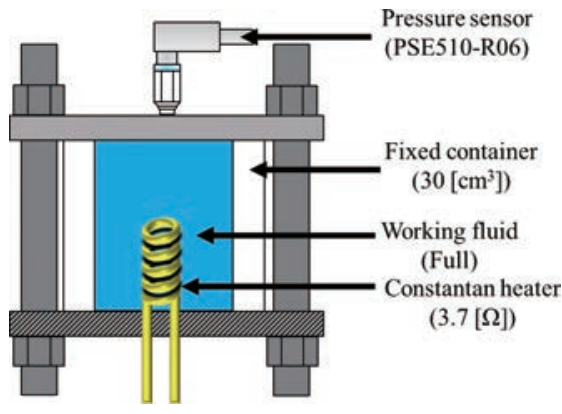

Fig. 8 Experimental device 


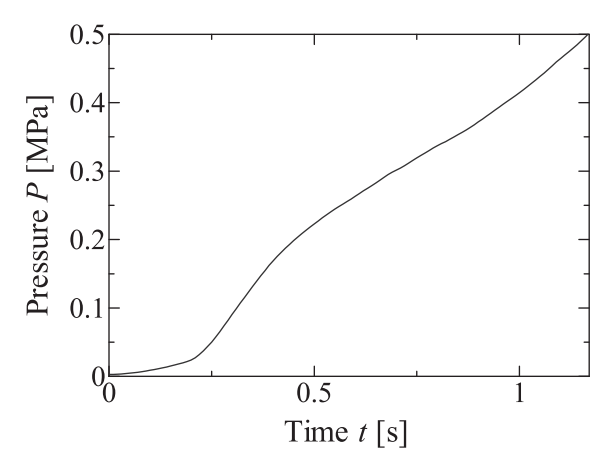

Fig. 9 Experimental result (time-pressure)

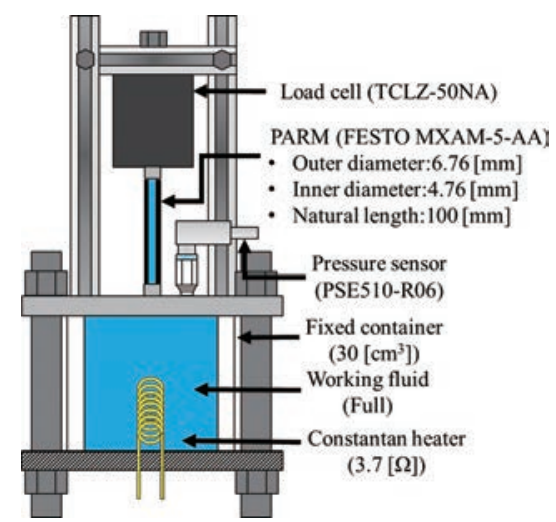

Fig. 10 Experimental device with load cell

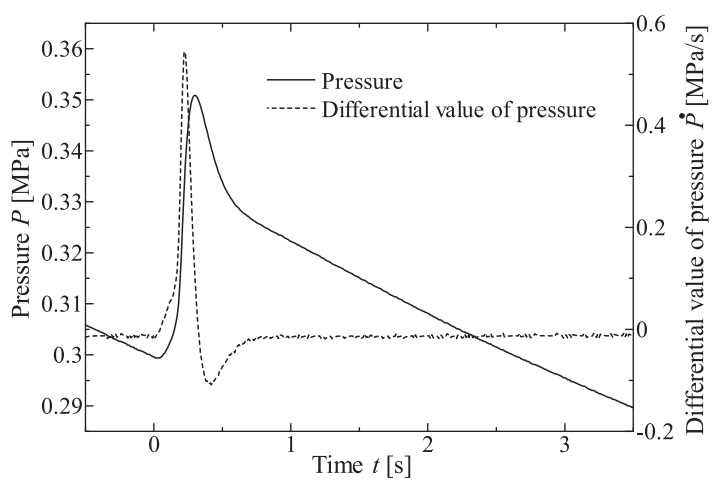

Fig. 11 Experimental results

\section{PARMの駆動実験（フィードバック制御）}

\section{1 装置構成と実験方法}

Fig. 10の装置を対象に内圧制御実験を行った，本実験で は, PI制御系を構成し, 各ゲイン值を比例ゲイン $400[\mathrm{~V} /$ $\mathrm{Pa}]$ ，積分ゲイン $3[\mathrm{~V} /(\mathrm{Pa} \cdot \mathrm{s})]$ とし，目標圧力 $P_{r e f}$ は $0.3 \rightarrow 0.35 \rightarrow 0.3$ [MPa gauge] とした。 また作動流体は20

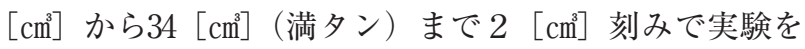
行った．全体の装置構成をFig. 12，ブロック線図をFig. 13 に示す. DSP（MTT s-BOX）を用いて制御信号（電圧 0 〜 $10[\mathrm{~V}] ）$ をアンプの役割である電源に与え，ヒー夕には $0 \sim 35[\mathrm{~V}]$ の電圧が印加される. ヒー夕の熱により容器 内の作動流体が加熱され, 気液相変化が発生する. 気液相 変化により発生した圧力を圧力センサ（SMC PSE510-R06）
により計測し，DSPへ圧力センサの信号を送ることで圧力 フィードバックを行った. データロガーを用いて記録した 值は, 圧力 $P$, ヒー夕の電圧 $E$, PARMの出力 $F$, 液温 $\theta$ で ある.

\section{2 実験結果}

各液量に対する圧力上昇と下降の時定数を Fig. 14に示す. この結果では30 [cm］の場合の圧力上昇と下降の時定数が 最も小さいといえる. $30\left[\mathrm{~cm}^{3}\right]$ の場合の実験結果（圧力 $P$, 電圧 $V$, 出力 $F$, 液温 $\theta$ ) をFig. 15 に示す. 目標圧力 0.35 [MPa gauge］に上昇する際の時定数は0.12［s］となった. この時，空冷による損失分を補償し，沸騰状態 $\left(95\left[{ }^{\circ} \mathrm{C}\right]\right.$ 以上）を維持するために定常的に必要な電圧は約 $15[\mathrm{~V}]$ であった，その後，目標圧力0.3 [MPa gauge］に下降する 際の時定数は $0.32[\mathrm{~s}]$ となった．このことから圧力の上昇 と下降に関して, 従来よりも応答性と制御性が共に向上し た制御方法を実現したといえる. 同じ圧力 $0.3[\mathrm{MPa}$ gauge］を維持するために, 実験開始直後と50［s］以降を 比較して, $50[\mathrm{~s}]$ 以降で電圧が下がっているのは液温が 上昇したためだと考えられる。また，0.35 [MPa gauge] に維持している時のPARMの出力は $26.4[\mathrm{~N}]$ であった.

\section{3 消費電力量}

気液相変化を用いてPARMを駆動させた際に電圧 $E$ を測 定し, そこから消費電力量 $W$ を(3)式を用いて求めた.

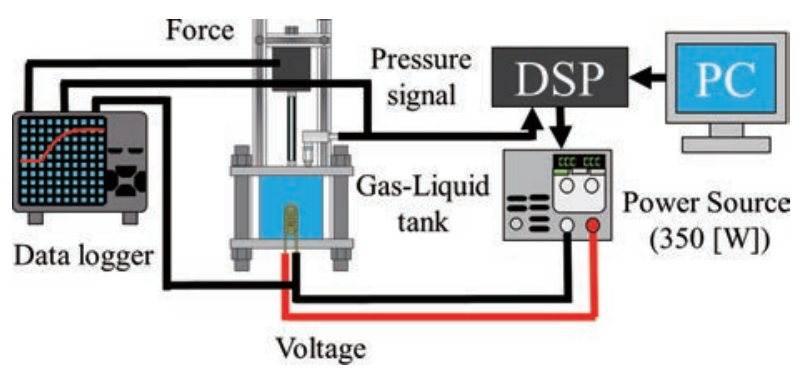

Fig. 12 Experimental configuration

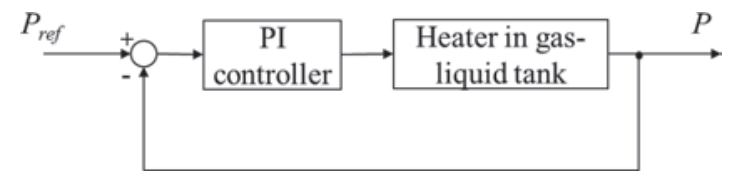

Fig. 13 Block diagram

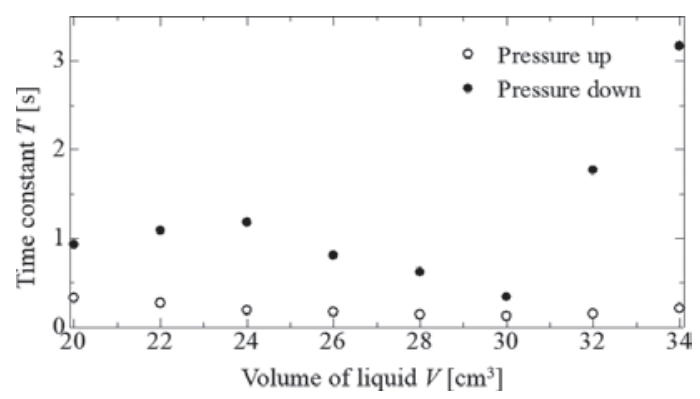

Fig. 14 Experimental result (volume-time constant) 


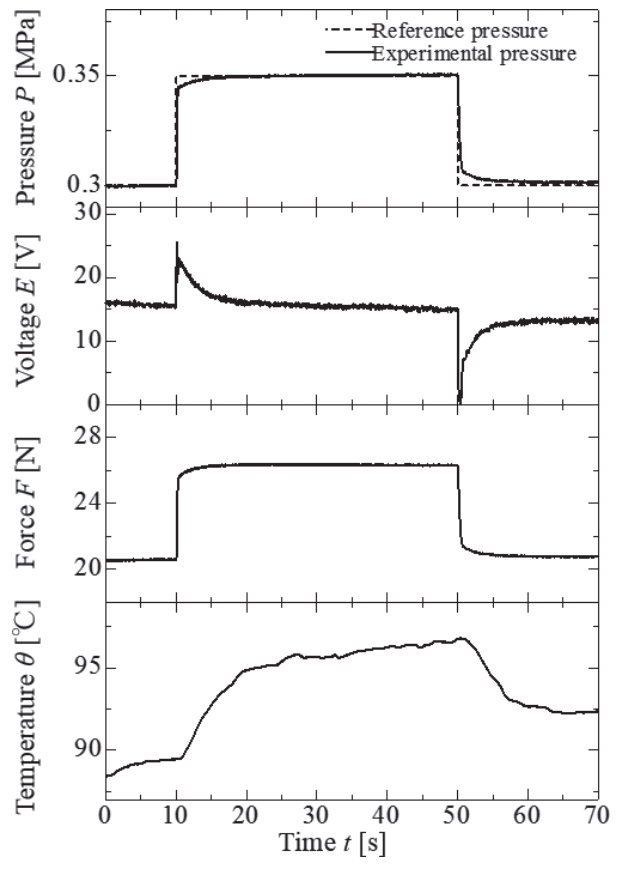

Fig. 15 Experimental results

$$
W=\int \frac{E^{2}}{R} d t
$$

電圧 $E$ と消費電力 $\dot{W}$, 消費電力量 $W$ をFig. 16に示す. 70 秒 間の消費電力量は4.39 [kJ] と求められた.

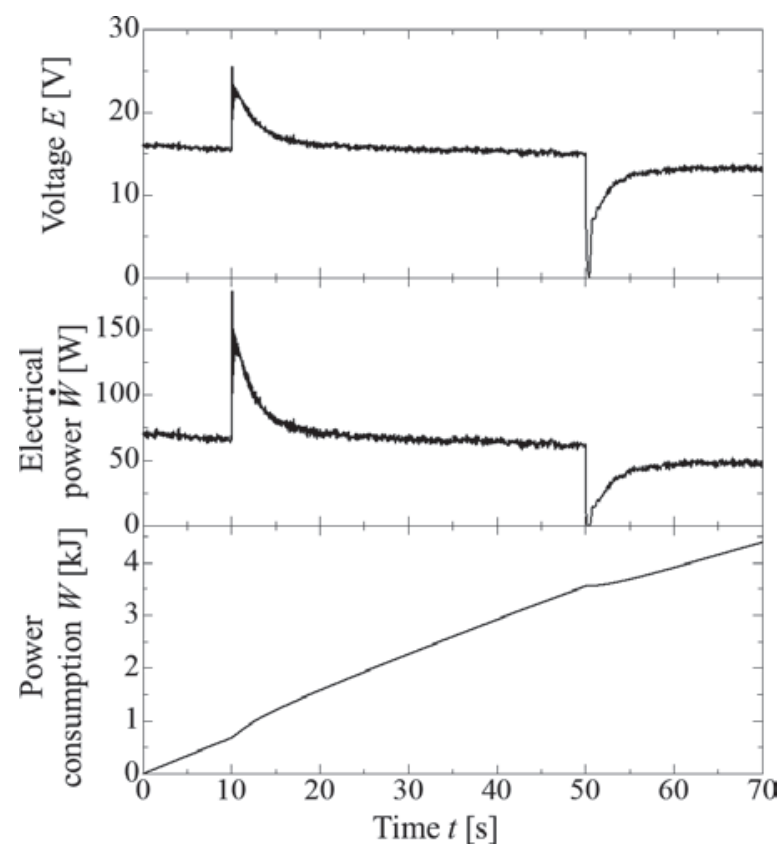

Fig. 16 Power consumption

\section{7. 周波数応答実験}

\section{1 実験条件}

本章では, 気液相変化により駆動されるPARMの動特性 を把握するため, 前章と同様にFig. 12の実験装置を用いて 周波数応答実験を行った. この時, 比例ゲインは $K_{P}=1,200$
$[\mathrm{V} / \mathrm{Pa}]$, 積分ゲインは $K_{I}=1.8[\mathrm{~V} /(\mathrm{Pa} \cdot \mathrm{s})]$ とし, 目標圧力 $P_{r e f}$ は式(4)のように定義した.

$$
P_{\text {ref }}=0.325+0.025 \sin (2 \pi f t)
$$

周波数は0.1 [Hz] から4.0 [Hz] までとし, 圧力と力の 応答を記録した。

\section{2 実験結果}

目標圧力 $P_{r e f}$ を入力值とし, 圧力 $P$ を出力值として, ゲイ ンと位相を求め, ボード線図を作成した。 その結果を Fig. 17に示す．位相は3.0 [Hz $]$ の時－85.7 [ํ] となり一 次遅れ系の収束位相 $-90\left[{ }^{\circ}\right]$ より大きくなるため, システ 厶は3.0 [Hz] まで概ね, 折点周波数 $1.5[\mathrm{~Hz}]$ の一次遅れ 系で近似できる. 周波数1.5 [Hz] の場合の実験結果を Fig. 18に示す.

\section{3 圧力と力の相関性}

周波数1.5 [Hz] の場合の圧力と力の関係をFig. 19に示す. 各周波数の場合の圧力の振幅 $A_{P}$, 力の振幅 $A_{F}$, 圧力の位 相 $\angle \phi_{P}$, 力の位相 $\angle \phi_{F}$ を測定し, 圧力 - 力 - 周波数の関 係を求めた．その結果をFig. 20に示す．このグラフより， 圧力と力の振幅比は一定ではない. また $4.0[\mathrm{~Hz}]$ の際に力 の位相は圧力の位相より約 $15\left[^{\circ}\right]$ 遅れている。これは, PARMの粘弾性 ${ }^{8)}$ が原因ではないかと考えられるが, 詳細

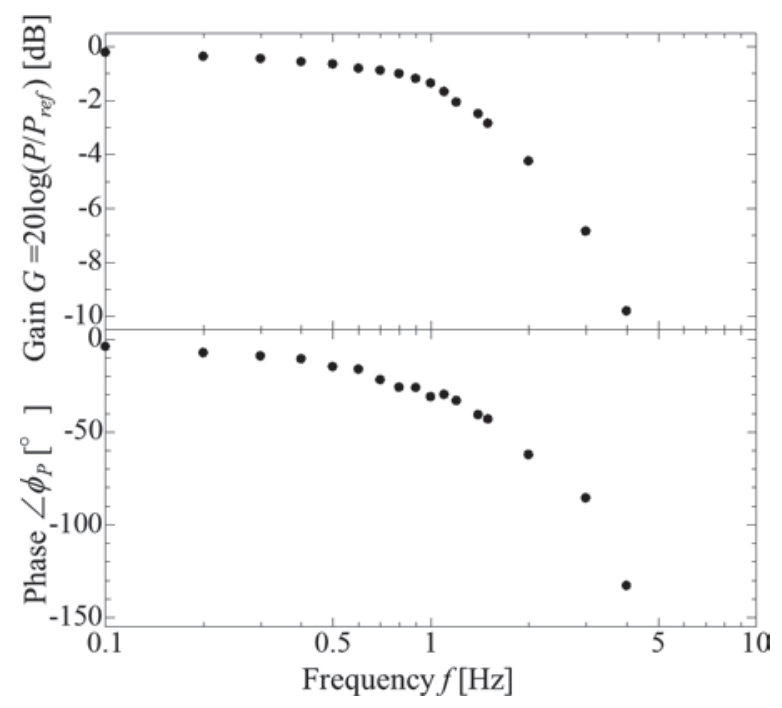

Fig. 17 Bode diagram

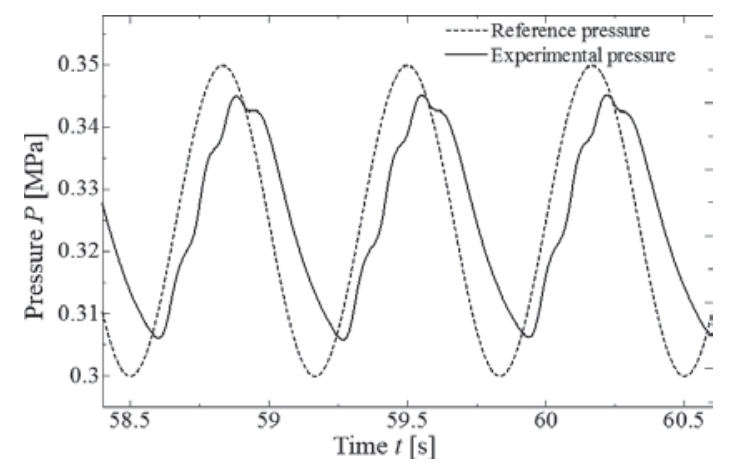

Fig. 18 Experimental result for $f=1.5[\mathrm{~Hz}]$ 


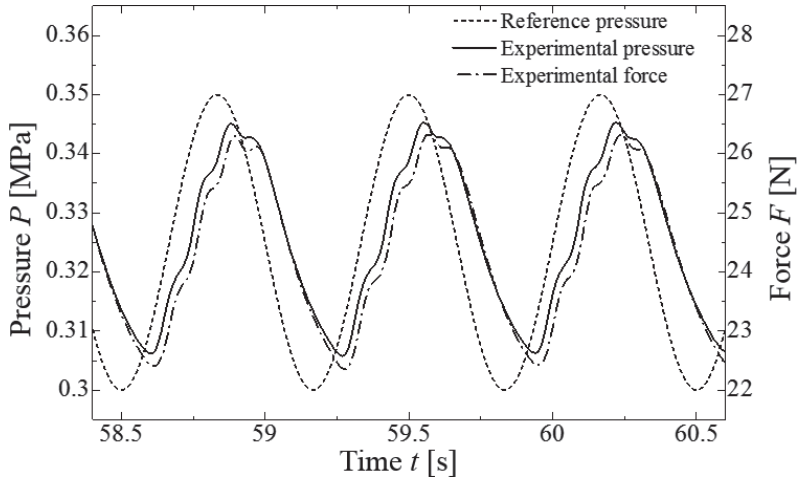

Fig. 19 Relationship between pressure and force for $f=1.5$ $[\mathrm{Hz}]$

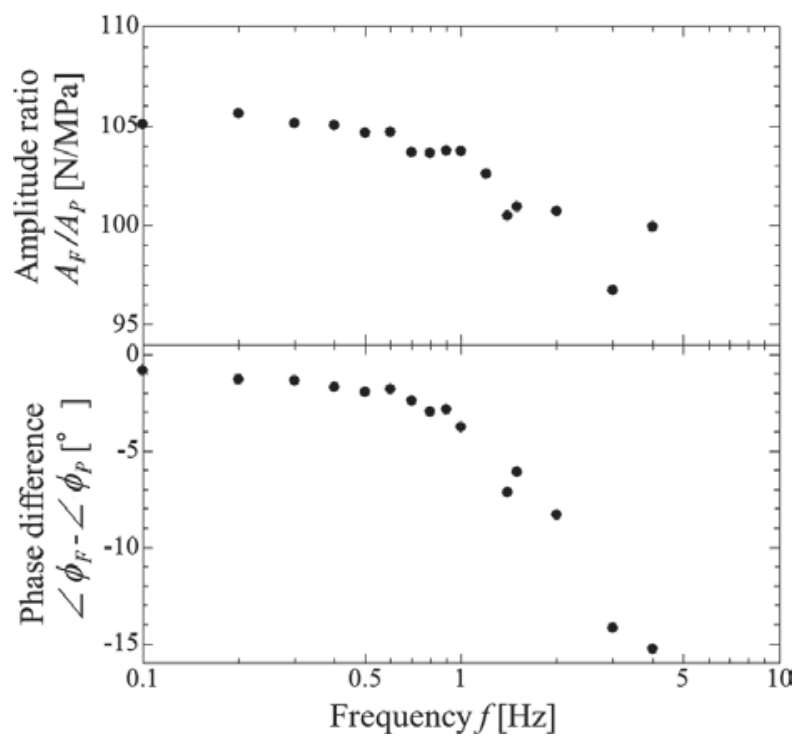

Fig. 20 Relationship between pressure and force (frequency domain)

は今後の研究課題である. 今後, 力制御を行う時には何ら かの位相の補償が必要であると考えられる。

\section{8. 結言}

本論文では，気液相変化により駆動される高応答なアク チュエータの力制御を実現することを目的とし，装置の製 作および制御系を適用し，PARMの駆動実験を行い，性能 を検証した。

まず，PARMの静特性を求め, 内圧・収縮率・力の関係 式と収縮率・体積の関係式を得た。次に，気液相変化を用 いた圧力発生実験を行い, 気液相変化による圧力の発生を 確認した.

その後, 圧力のPI制御系を構成し, PARMの内圧を気液 相変化により制御する実験を行った．ステップ応答実験の
目標圧力は $0.3 \rightarrow 0.35 \rightarrow 0.3[\mathrm{MPa}$ gauge $]$ であり, 内圧を変 動させた際の圧力, 電圧, PARM出力, 液温を測定した. 目標圧力 0.35 [MPa gauge ] に上昇する際の時定数は 0.12 [s]，目標圧力 0.3 [MPa gauge］に下降する際の時定数は 0.32 [s] となった. また, PARMの出力は制御を行うこと で，約26.4 [N] の保持に成功した。この内圧制御を行った 場合の消費電力量は $4.39[\mathrm{~kJ}]$ と求められた.

さらに, 周波数応答実験を行い, 圧力 - 力 · 周波数の関 係を求めた。これらの結果より, 気液相変化により駆動さ れるPARMは, 数ヘルッの動特性を要するロボットアーム や鉗子などの制御に十分適用できる可能性が示された。

\section{参 考 文 献}

1 ）則次俊郎 : 空気圧アクチュエータ, 日本ロボット学会 誌, Vol. 15, No. 3, 355/359 (1997)

2) Kenji Kawashima, Takahiro Sasaki, Toshiyuki Miyata, Naohiro Nakamura, Masato Sekiguchi and Toshiharu Kagawa: Development of Robot Using Pneumatic Artifi cial Rubber Muscles to Operate Construction Machinery, Journal of Robotics and Mechatronics, Vol. 16, No. 1, 8/15 (2004)

3 ）松田信一, 大野学, 泉俊之, 加藤重雄 : 金属ベローズ 型気液相変化アクチュエータ（内視鏡下外科手術用処 置具への利用), 精密工学会誌, Vol. 71, No. 6,723/728 (2005)

4) 吉澤達哉, 加藤友規, 大野学, 加藤重雄 : 気液相変化 駆動式ゴム人工筋アクチュエータの基礎特性，日本機 械学会関東支部総会講演会講演論文集，67/68（2010）

5 ) 本多駿太, 加藤友規, 程明昭, 小笠原利樹, 大野学 : 気液相変化により駆動されるゴム人工筋アクチュエー 夕の製作，春季フルードパワーシステム講演会講演論 文集，97/99 (2014)

6 ) 藤本真作, 小野敏郎, 逢坂一正, 趙子否 : 空気圧ゴム 人工筋のモデリングと拮抗駆動型システムの制御系設計, 日本機械学会論文集 $(\mathrm{C}$ 編 $), 73$ 巻730号, 1777/1785 (2007)

7 ) 香川利春, 藤田壽憲, 山中孝司：人工筋アクチュエー 夕の非線形モデル，計測自動制御学会論文集，Vol. 29, No. 10, 1241/1243 (1993)

8 ）加藤友規, 大野学, 東知明, 只野耕太郎, 川嶋健嗣, 香川利春 : ゴムベローズを用いた高減衰空気圧ゴム人 工筋の提案と特性解析, 日本フルードパワーシステム 学会論文集, 42巻 6 号, 114/119（2011） 